\title{
AN EVALUATION OF THE PRODUCTIVITY OF ALAGBA SERIES FOR UPLAND CROPS PRODUCTION IN THE HUMID AGRO ECOLOGICAL ZONE OF NIGERIA *NWACHOKOR, M.A. ${ }^{1}$ and ORIMOLOYE, J.R. ${ }^{2}$ \\ DOI:http://dx.doi.org/10.4314/ejesm.v5i3.11 \\ Received $26^{\text {th }}$ March 2012; accepted $2^{\text {nd }}$ June 2012
}

\begin{abstract}
Studies were carried out on Alagba series in the humid agro ecolocological zone of Nigeria to evaluate their productivity on the basis of their physicochemical properties. Soil constraints inherent in the soils which negatively impact on their productivity were scientifically identified. Thereafter, appropriate measures to ameliorate the constraints were proffered in order to enhance the productivity of the soils. Among the constraints identified were soil acidification, low effective cation exchange capacity and susceptibility to erosion due to the clayey texture throughout the profile. This kind of texture not only made the soils less productive for deep rooted crops but also caused difficulties in harvesting. Liming and the use of acid-tolerant species were appropriate measures to ameliorate the acidity constraints, while incorporation of organic materials into the soils in combination with liming were the appropriate measures to enhance the effective cation exchange capacity. Erosion control and maintenance of surface cover were to be given high priority, while tillage should be limited to only when soil was drier than the plastic limit. Soil organic carbon should be maintained or increased due to its role in many important soil properties that have a bearing on soil productivity.
\end{abstract}

Keywords: Productivity, inherent soil constraints, Alagba Series, humid agroecological zone, Nigeria

\section{Introduction}

One of the major causes of food insecurity and poverty in many countries of Africa including Nigeria is declining soil productivity arising mainly from land degradation (Thiombiano, 2000; FAO, 2002; UNDP/GEF, 2004). In most cases, land degradation is as a result of mismanagement of natural resources by land users, especially by resource - poor farmers who have no access to land use advice that are from appropriate land use planning (Bationo et al; 2006). Efforts to reverse this unwanted trend must therefore begin with conscientious action to acquire adequate knowledge of the land resources of the continent through standard soil resource inventory procedure (Soil Survey Staff, 1951) to adequately characterize the soils (FAO, 2006) for land use planning for sustainable production.

As a component of the terrestrial ecosystem, soil fulfills many functions including those that are essential for sustaining plant growth. The functions include partitioning of applied water into drainage and/or run-off, storage of plant-available water, supply of adequate oxygen to roots, provision of favourable conditions of seedling establishment, storage of nutrients essential to plant growth, suppression of plant pathogens and immobilization of contaminants. These functions constitute the criteria against which soil quality is assessed (Brady and Weil, 2002; Moody and Cong, 2008). The soil characteristics that are used to assess its productivity or ability to fulfill these functions include soil texture, $\mathrm{pH}$, organic carbon, cation exchange capacity and soil depth. Soils differ in their capacity to fulfill these functions due to differences in their inherent characteristics. The productive potential of a soil is limited by its inherent constraints. Identifying and managing these constraints is therefore fundamental to formulating sustainable production systems.

This work is an effort to identify such soil constraints that are inherent in Alagba series, found mainly in the humid agro ecological zone of Nigeria (Dudal, 1980).

\section{Materials and Methods \\ Study Area}

The study was carried out at a previously classified site in Alagba town in Southwestern Nigeria. Alagba town is situated within latitudes $6^{\circ} 7^{\prime}$ and $6^{\circ} 8^{\prime}$ North and longitudes $4^{\circ} 8^{\prime}$ and $4^{\circ} 9^{\prime}$ East. Alagba series is formed from sedimentary rocks and has annual precipitation of $1900 \mathrm{~mm}$. Alagba series is found in the humid agro ecological zone of Nigeria.

\section{Sample collection}

At the site a representative profile pit was systematically located, dug and described (FAO,

${ }^{\text {I}}$ Department of Agronomy, Faculty of Agriculture and Agricultural Technology, Benson Idahosa University, P.M.B 1100, Benin City, Edo State, Nigeria. $\quad{ }^{2}$ Rubber Research 
2006). Samples were collected from the genetic horizons of the profile. The soil samples were then taken to the laboratory and analyzed for their physicochemical properties. Among the physicochemical properties required for the study were $\mathrm{pH}\left(\mathrm{H}_{2} \mathrm{O}\right)$, organic carbon, extractable bases, extractable acidity, aluminum saturation, cation exchange capacity, effective cation exchange capacity (ECEC), base saturation, soil texture and soil depth.

\section{Sample analyses}

The percentages of the primary separates (sand, silt and clay) were determined by the hydrometer method (Day, 1965). $20 \mathrm{ml}$ of $\mathrm{N}_{\mathrm{a}} \mathrm{OH}$ was used as a dispersing agent. The textural classes were then assigned according to Soil Taxonomy (Soil Survey Staff, 1998). The organic carbon of the soils was determined by the chromic digestion method (Jackson, 1958). The soil pH $\left(\mathrm{H}_{2} \mathrm{O}\right)$ was determined in $1: 1$ soil - water ratio suspension (Schofield and Taylor, 1955). The exchangeable acidity was determined in two ways: by the neutral acetate method, and by unbuffered potassium chloride method. The neutral acetate the extractable acidity was found by difference between the CEC value obtained by the $\mathrm{Mg}(\mathrm{OAc})_{7}, \mathrm{pH} 7$ (Jackson, 1958) and the sum of $1 \underline{\mathrm{N}} \mathrm{NH}_{4} \mathrm{OAc}$ exchangeable bases (i.e., $\mathrm{Ca}, \mathrm{Mg}, \mathrm{Na}$ and $\mathrm{K}$ ). The extractable acidity by the unbuffered potassium chloride method was determined by

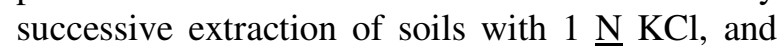
then the amounts of exchangeable $\mathrm{H}$ and $\mathrm{Al}$ in the extracts were determined by the Fluoride titration procedure described in Soil Survey Staff (1972). The CEC was determined by the method described by Jackson (1958). The ECEC was taken as the sum of the extractable bases and the unbuffered $\mathrm{KCl}$-extractable acidity.

Lastly, from the physicochemical data of the soils their individual attributes and constraints were systematically identified by applying the Soil Constraints and Management Package (SCAMP) (Moody and Cong, 2008) assessment

\section{Results and Discussion}

The physicochemical properties of Alagba series are shown in Table 1. Alagba series have earlier been classified as Oxic Paleustults in Soil Taxonomy, and as Dystric Nitosols under the FAO soil classification system by Nwachokor (1982). These soils are deep, so they can support both shallow and deep rooted crops. They have clay texture throughout the profile. Deckers (1993) had reported that Nitosols have an appreciable level of fertility due to the clay in the subsoil, which can retain considerable amounts of plant nutrients. However, a heavy texture can constitute an important constraint to crop production. A horizon of clayey texture frequently restricts root growth, and also causes harvesting difficulties for root crops. Again, clayey soils are not productive for crops that do not tolerate prolonged soil wetness. They have low permeability, a constraint which makes them remain wet for a longer period than soils of lighter texture. To expatiate, the soil characteristics associated with clayey texture include low infiltration rates, moderate- high plant- available water - holding capacity, and some restriction on water movement leading to periodic waterlogging or, on sloping sites, potential for high run-off. This is collaborated by Ogunkunle (1993) who found that Alagba soil series in southwestern Nigeria was only marginally suitable (S3) for oil palm cultivation due to the major limitations of particle size( and soil fertility), using the FAO system. The clayey texture also makes Alagba series moderately to highly susceptible to mechanical compaction, and difficult to till thereby causing harvesting difficulties for root crops. This is collaborated by the work of Kang and Juo (1983) which revealed that the productivity of Ultisols is poor due to their susceptibility to erosion and compaction, in addition to other limitations.

To prevent compaction, Alagba soils should be tilled only when they are drier than their plastic limit. Surface cover should be maintained to prevent soil erosion hazard.

Alagba soils were acidic, the mean $\mathrm{pH}\left(\mathrm{H}_{2} \mathrm{O}\right)$ being less than 7.0 and having a base saturation which is less than $100 \%$ (Coleman and Thomas, 1967). The acidic nature of Alagba series may be attributed partly to the heavy tropical rainfall. Onwueme and Sinha (1991) have reported that in regions of high annual precipitation, even soils derived from alkaline parent materials become acidic due to the leaching away of basic cations, namely, calcium $\left(\mathrm{Ca}^{++}\right)$, magnesium $\left(\mathrm{Mg}^{++}\right)$, potassium $\left(\mathrm{K}^{+}\right)$and sodium $\left(\mathrm{Na}^{+}\right)$by rainwater, and the replacement of many of them by hydrogen ions $\left(\mathrm{H}^{+}\right)$. 
Soil Depth (cm)

\begin{tabular}{|c|c|c|c|c|c|c|}
\hline Properties & $0-5$ & $5-22$ & $22-50$ & $50-80$ & $80-110$ & $110-130$ \\
\hline $\mathrm{pH}\left(\mathrm{H}_{2} \mathrm{O}\right)$ & 5.10 & 5.10 & 5.00 & 5.00 & 5.05 & 5.08 \\
\hline Organic carbon $\left(\mathrm{g} \mathrm{kg}^{-1}\right)$ & 2.15 & 0.73 & 0.29 & 0.20 & 0.08 & 0.04 \\
\hline Ex. H & 0.10 & 0.07 & 0.13 & 0.17 & 0.04 & 0.04 \\
\hline \multicolumn{7}{|l|}{ Extractable $\mathrm{Al}\left(\mathrm{cmol} \mathrm{kg}^{-1}\right)$ : } \\
\hline $\mathrm{Ca}$ & 1.50 & 0.65 & 0.55 & 0.30 & 0.30 & 0.20 \\
\hline Mg & 1.27 & 0.87 & 0.56 & 0.25 & 0.40 & 0.30 \\
\hline $\mathrm{Na}$ & 0.09 & 0.09 & 0.12 & 0.01 & 0.01 & 0.09 \\
\hline $\mathrm{K}$ & 0.03 & 0.03 & 0.06 & 0.01 & 0.03 & 0.04 \\
\hline Extractable acidity $\left(\mathrm{cmol} \mathrm{kg}^{-1}\right)$ & 0.10 & 0.53 & 0.91 & 0.95 & 1.15 & 1.19 \\
\hline $\operatorname{ECEC}\left(\mathrm{cmol} \mathrm{kg}^{-1}\right)$ & 2.99 & 2.19 & 2.20 & 1.62 & 1.89 & 1.82 \\
\hline Neutral acetate CEC $\left(\mathrm{cmol} \mathrm{kg}^{-1}\right)$ & 10.75 & 7.75 & 10.00 & 8.25 & 9.50 & 11.25 \\
\hline Base Saturation $\left(\mathrm{g} \mathrm{kg}^{-1}\right)$ & 97 & 76 & 59 & 41 & 39 & 35 \\
\hline Sand (\%) & 38 & 42 & 40 & 36 & 36 & 32 \\
\hline Silt (\%) & 13 & 2 & 1 & 1 & 1 & 1 \\
\hline Clay (\%) & 49 & 56 & 59 & 63 & 63 & 67 \\
\hline Gravel (\%) & 5 & 10 & 8 & 4 & 8 & 57 \\
\hline Textural Class & Clay & Clay & Clay & Clay & Clay & Clay \\
\hline Extract Aluminum (Al) $\left(\mathrm{cmol} \mathrm{kg}^{-1}\right)$ & 0.08 & 0.46 & 0.78 & 0.78 & 1.11 & 1.15 \\
\hline Al saturation (as $\%$ of ECEC) & 3 & 21 & 36 & 48 & 59 & 63 \\
\hline
\end{tabular}


The $\mathrm{pH}\left(\mathrm{H}_{2} \mathrm{O}\right)$ of Alagba series ranged from $5.00-5.10$. These values fall within the SCAMP diagnostic $\mathrm{pH}$ range of $4.6-5.5$. This $\mathrm{pH}$ range denotes significant soil acidification, a constraint which can be due to natural processes (eg., leaching of basic cations by heavy tropical precipitation), or to the longterm use of highly intensive acidifying agricultural practices such as high application rates of ammonium-based $\mathrm{N}$ fertilizers, removal of large amounts of harvested product or mineralization of nitrate from decomposing leguminous plant species. In this $\mathrm{pH}$ range aluminum ( $\mathrm{Al})$ or manganese $(\mathrm{Mn})$ toxicity is probable. Deficiencies of molybdenum (Mo), calcium $(\mathrm{Ca})$ magnesium $(\mathrm{Mg})$, and potassium $(\mathrm{K}+)$ can occur, as a result of the reasons given above. Again, activity of some soil microorganisms (especially nitrifiers) is reduced in this kind of acid condition. If productive yields are to be maintained, amelioration of soils in this $\mathrm{pH}$ range will be necessary, and Moody and Cong (2008) have observed that this is often economically viable. The use of acid-tolerant species and addition of organic materials to such soils may help to ameliorate soil acidity. Alagba series also had the constraint of aluminum toxicity, estimated from aluminum saturation (expressed as percentage of effective cation exchange capacity). Aluminum (Al) toxicity in soils can be corrected by liming. The Al saturation of the soils ranged from $3-63 \%$. Based on the findings of Dierolf et al. (2001), about 0.5 tonnes/ha of lime would be required to lower the $\mathrm{Al}$ saturation of the soils to the range of 30 - $40 \%$, to make the soils productive for the cultivation of several upland crops such as maize and groundnut.

The cation exchange capacity (CEC) of soils commonly ranges from $3-50 \mathrm{cmol} \mathrm{kg-}{ }^{1}$ (Brady and Weil, 2002). Therefore, Alagba series could be said to have low CEC. This could be attributed to the fact that soils of the humid tropics are characterized by low organic matter and clay, and oxides and hydroxides of iron and aluminum; these soils have very little $2: 1$ clay minerals, and the clay is predominantly kaolinitic (Gallez et al, 1976). The effective cation exchange capacity (ECEC) of Alagba series was also low. A low
ECEC is a soil constraint because this implies a low capacity to hold cations against leaching (Sanchez, 1976). Therefore, applying high rates of a cation such as $\mathrm{K}^{+}$in fertilizer would increase the likelihood of losses due to leaching. To ameliorate this constraint of low ECEC, management options should include liming to increase soil $\mathrm{pH}$; the resultant increase in ECEC is a benefit of lime application to variable - charge soils that is often not recognized (Moody and Cong, 2008). Also, due to the role of soil organic carbon (SOC) in many important soil properties, SOC levels should be maintained or increased by mulching and by incorporating green - manure crops (eg. legumes or forage grasses) into the topsoil. In addition, all crop residues in the field where the crop has been grown should be retained there, they should not be burnt. Again, erosion should be controlled to prevent the offsite movement of topsoil, which is richer in SOC than subsoil. Minimum or zero-tillage farming systems is encouraged to reduce the loss of SOC from cultivation. Also to be practiced is strip and alley cropping which allow the application of plant residues from the strip or alley crop to the inter-row area. SOC levels could also be increased by applying organic materials (such as animal manure, composted municipal waste, sewage sludge and locally available industrial organic wastes) obtained from off-site.

\section{Conclusion}

This work has shown that Alagba series have some inherent soil constraints which could reduce their productivity for upland crops production. The management measures needed to ameliorate the constraints have been clearly outlined, and this would enhance the productivity of the soils if fully implemented.

\section{References}

Bationo, A., Hartemink, A., Lungu, O., Naimi, M., Okoth, P., Smaling, E. and L. Thiombiano (2006), African Soils: Their Productivity and Profitability of Fertilizer Use. Africa Fertilizer Summit 9 - 13 June 2006, Abuja, Nigeria.

Brady, N.C. and Weil. R.R. (2002), The Nature and Properties of Soils. Prentice - Hall, 
Inc. Pearson Education, Upper Saddle River, New Jersey 07458.

Coleman, N.T. and Thomas, G.W. (1967), Basic Chemistry in Soil Acidity. Agro Monograph No. 12, ASA Madison, Wisconsin, pp: $1-41$.

Day, P.R. (1965), Particle Fractionation and Particle Size Analysis. In: Methods of Soil Analysis, Part 1: ASA Monograph No. 9, American Society of Agronomy, Madison, USA. Pp. 545 - 567.

Deckers, J. (1993), "Soil Fertility and Environmental Problems in Different Ecological Zones of the Developing Countries in Sub-Saharan Africa", In: The Role of Plant Nutrients and Sustainable Food Production in Sub-Sharan Africa, H. Van Reuler and W.H. Prins (Eds.), Vereniging van Kunstmest Producenten, Laidschendam, The Netherlands. Dierolf T., Fairhurst T. and Mutrert E. (2001), Soil fertility Kit: a toolkit for acid, upland soil fertility management in Southeast Asia. Potash and Phosphate Institute: Singapore.

Dudal, R. (1980). "Soil Related Constraints to Agricultural Development in the Tropics", IN:

Proceedings Symposium on Properties for Alleviating Soil - Related Constraints to Food Production, pp. 23 - 40, IRRI - Cornel University, Los Banos,Philippines.

FAO (2002), Land Degradation Assessment in Drylands, Rome, Italy. 18 p.

FAO (2006). Guidelines for Soil Profile Description and Classification ( $^{\text {th }}$ edition). FAO, Rome.

Gallez, A., Juo, A.S.R. and Herbillon, A.J. (1976), Surface and charge characteristics of selected soils in the tropics. Soil Sci. Sco. Am. Proc., Vol. 4. July - August Issue.

Jackson, M.L. (1958), Soil Chemical Analysis. Englewood Cliffs, N.J. Prentice - Hall. Pp: 57 $-67$.

Kang, B.T. and Juo, A.S.R. (1983), Managemengt of low activity clay soils in tropical Africa for food crop production. Pp.450-470. In: Beinroth, F.H., Neel H., Eswaran H. (eds.). Proceedings of the Fourth
International Soil Classification Workshop, Kigali, Rwanda. Brussels, Belgium: ABOSAGCD.

Moody, P.W. and Cong, P.T. (2008), Soil Constraints and Management Package (SCAMP): Guidelines for sustainable management of tropical upland soils. Australian Centre for International Agricultural Research. Canberra ACT 2601, Australia.

Nwachokor, M.A. (1982), Cation Exchange Characteristics and Classification of Some Southern Nigerian soils. B. Agric Thesis, University of Ife, Ile -Ife, Nigeria.

Ogunkunle, A.O. (1993), Soil in land suitability evaluation: an example with oil palm in Nigeria. Soil Use and Management, 9(1), 35-39.

Onwueme, I.C. and Sinha, T.D. (1991). Field Crop Production in Tropical Africa: Principles and Practice. CTA, Ede, The Netherlands.

Sanchez, P.A. (1976). Properties and Management of Soils in the Tropics. Wiley, New York.

Schofield, R.K. and Taylor, W. (1955). The Measurement of Soil pH. Soil Sci. Soc. Am. Pro., 10:164-167.

Soil Survey Staff (1951), Soil Survey Manual $\left(2^{\text {nd }}\right.$ ed.). U.S Department of Agriculture Handbook No. 18, U.S Government Printing Office, Washington DC.

Soil Survey Staff (1972), Investigation Report No. 6 G1d, USDA.

Soil Survey Staff (1998). Keys to Soil Taxonomy. USDA Natural Resources Conservation Service, Washington, D.C.

Thiombiano, L. (2000), Etude des Facteurs e daphiques et Pedopaysaguques Dans le Development de la Desertification en Zone Sahlienne du Burkina Faso. These de Doctorat d Etat, Vol. 1, 200p. Plus Annexes, University de Cocody, Abidjan, Cote d' Ivoire.

UNDP/GEF (2004), Reclaiming the Land Sustaining Livelihoods: Lessons for the future. United Nations Development Fund/Global Environmental Facility, November, 2004. 